\title{
デサ・サングラ・アグン（インドネシア・マドゥラ島）における住居 および集落の空間構成
}

\section{SPACE FORMATION OF THE MADURESE SETTLEMENTS (DESA SANGGRA AGUNG) IN MADURA ISLAND, INDONESIA}

\author{
山本直彦*, 布野修司**, 脇田祥尚***, 三井所 隆史**** \\ Naohiko YAMAMOTO, Shuji FUNO, Yoshihisa WAKITA \\ and Takashi MIISHO
}

The purpose of this paper is to analyze the principles of space formation of Madurese houses, house compounds and villages. In Indonesia, many settlements of Proto-Malay tribes like Batak, Toraja are formed as parallel disposition pattern. Madurese settlements also follow the same pattern. Compared to the settlements of other tribes, Madurese settlements are significant as a prototype because they realize that pattern in the smallest scale. It is also pointed out that Javanese and Balinese settlements in pre-Hindu period followed the same pattern. The analysis on Madurese settlements might reveal the basic rules of space formation of the settlements in Indonesia.

This paper firstly tries to grasp the settlement patterns in rural regions in Madura Island. After looking at all the regions in Madura Island, Sanggra Agung is chosen to be surveyed more specifically. Judging from the result of the survey, it is concluded that Islamic influence has played an important role to keep indigenous space formation system of Madurese settlements particularly in western Madura.

Keywords: Madura Island, Desa Sanggra Agung, parallel disposition pattern settlements, Islam, Indonesia マドゥラ島、デサ・サングラ・アグン、平行二列対面型配置、イスラーム、インドネシア

1.はじめに

\section{1-1 研究の背景・目的}

本稿では、インドネシアのマドゥラ島の住居および集落を対象と して、その空間構成の原理を、主として生活行為と居住空間の関係 に着目することによって明らかにすることを目的とする。

マドゥラ島は、マドゥラ海屼を介して、東部ジャワの北部沿岸地 域上向かい合う位置にある（図 1)。マドゥラ人は、インドネシア で、ジャワ人、スンダ人に次いで 3 番目に多い人口を推し、諸民族 の中でも、特に熱心にイスラームを信仰することで知られる。

インドネシア島嶼部には、バタック・トバ、トラジャ、ニアス島 の例ように主屋あるいは穀倉、釜屋、家畜小屋などの付属屋 ${ }^{*}$ が、 中庭を介して平行に並ふ:平行二列対面型"2の住居配置が広く見られ るが、マドゥラ島の住居も同様の構成をとる。マドゥラの平行二列 対面型の構成は、ごく近い血縁者のみが居住する個々の屋敷地にお いて見られ、他民族の場合と比較する上、最も小規模な形式といえ る。マドゥラ島の住居は、平行二列対面型の住居配置のひとつの原 型を保持してきた可能性があり、インドネシアにおける住居の基本 的な構成原理を考察する上で重要な事例と考えられる。

また、マドゥラ島に隣接するジャワ島やバリ島の住居は、ヒン ドゥ一文化の影響を受けていることが指摘される。そしてR，タン
“3は、ヒンドゥー文化が持ち込まれる以前のバリの土着の集落が、村 の寺を頂点に持つ平行二列対面型の住居配置を持っていたことを指 摘している。東部ジャワのモジョクルトMojokerto では、マジャパイ 卜王朝最盛期の 14 世紀後半の寺院遺跡から、平行配置される住居群 が彫られたレリーフが発掘されている。マドゥラ島の住居配置は、 こうしたかつてジャワやバリに見られた住居配置と、大きく関係す る上考えられる。また、ジャワ、バリ、ロンボクとマドゥラの住居 は東南アジアで例外的に、土間式であるという共通性を持っている。 マドゥラ島の住居についての研究は、ジャワ、バリを中心とした周 辺諸島の既往の住居研究によっても極めて重要である。

\section{1-2 研究の方法}

まず既往の研究“艺もとにマドゥラ島全域を踏查し、適宜選んだ 計 17 集落”ににおいて、住居平面と構造を確認し住居配置の実測を 行った。これをもとにマドゥラ島の住居および集落の地域類型を明 らかにしたここの地域類型の抽出は、本研究の成果のひよつである。 次に、その地域類型に従って選定した典型的な集落であるデサ． サングラ・アグン Desa Sanggra Agung（および比較対象よして選定 したデサ・グル・グルGuluk Guluk) に住み込み、より詳細な調查を 行ったっその内容は以下のようである。

1)集落配置図の作成：住区の範囲で配置図を取り、これから屋教地

\footnotetext{
$*$ 京都大学大学院建築学尃攻 大学院生.工修

** 京都大学工学部建築学科 助教授・工博

*** 島根女子短期大学 講師 · 工修

**** 京都大学大学院建築学守攻 大学院生
}

Graduate Student, Dept. of Architecture, Faculty of Engineering, Kyoto Univ., M. Eng

Assoc. Prof., Dept. of Architecture, Faculty of Engineering, Kyoto Univ., Dr. Eng. Lecturer, Shimane Women's College, M. Eng.

Graduate Student, Dept. of Architecture, Faculty of Engineering, Kyoto Univ. 


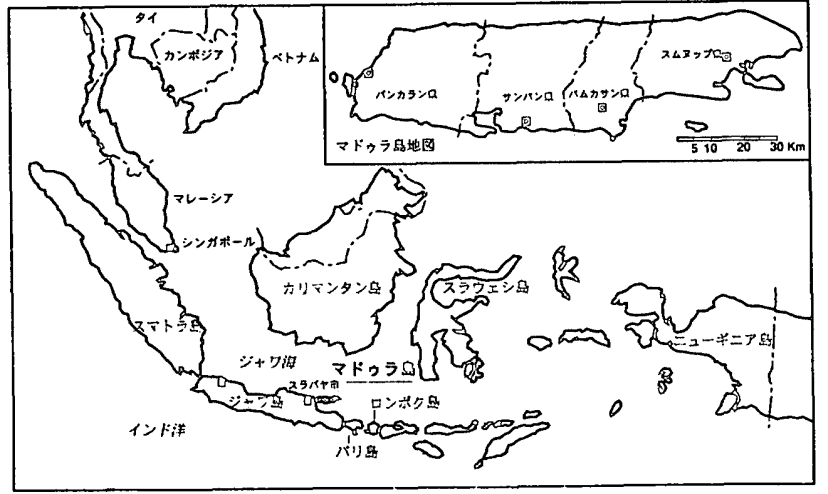

图 1 マドゥラ島の位要

の平面構成を類型化し、聞き取り調査を行う屋敖地を選定した。 2)生活行為之居住空間の関係を中心とした聞き取り調查:まず家具配 置を含む住居平面図を取り、家族構成を把握した上て、、各主屋と付 属屋の所有関係と相続関係を調でた。さらに就寝、食事、礼拝、接 客を中心に、それぞれの生活行為か、、性別による違いを含めて、住 居のどの部分で行われるかを調べた。また、補足的に各榑の建設年 代と建設組織についても聞き取りを行った。

3)住居断面図の記録: 典型的な主屋、付属屋の構造について、部材名 称の聞き取りと詳細な実測を行った。尚、本稿で述べる部标、室、榑 などの名称は、すべてマドゥラ語である。

1994年10月 4 日 25 日に地域類型調查と住み込み予備調查、1995 年9月9日〜10月 8 日に地域類型の補足と住み込み本調查を行った。

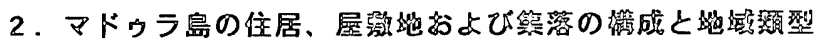

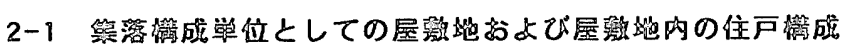

マドゥラ島の集落については、田中則雄”が、C.v.ファレンホーへ ンとクントウィジョヨを引いている。

C.v.ファレンホーヘンは、ジャワ・マドゥラの集落を分類するなか で、ジャワの集落は、生坦之樹木に包まれ田畑の中に巨大な浮島の ように存在し、単一の村落を形成しているのに対し、マドゥラの集 落は「地域的な統一体之言うよりは、孤立した屋敷地の集合体か、小 集落の集合体にすぎない」としている。また、クントウィジョヨは、 マドゥラの集落は「小さな単位て散在し散村の形態をとっている。 人々は村落の中で生活しているのてはなく、壁または簡単な柵で囲 まれた屋敷の中て、血縁の $4 、 5$ 戸の核家族の小グループを中心に して生活している」と述心、集落内の屋隺地の独立性の高さを指摘 している。“さらにクントウィジョヨはこうした散村的な形態をと る原因として、マドゥラ島の烟作中心の生態条件を挙げる。自然条 件が敩しく水田耕作が難しいマドゥラては、生業の中心は畑作であ る。そのため各戸は、それぞれの耕地と家畜を持つ。つまり、水田 耕作に関わる水利組織などを持たないマドゥラの集落は共同体とし て組織される必要がなかったとされるのである。

また、宮本謙介は、集落間の結合も比較的ルースであ、その理 由として、かつて各耕地が上級支配者層の封土として組み込まれて いたことを指摘している。

マドゥラ島の集落が、独立性の高い屋敷地を基本的な構成単位と していることは、以上からおよそうかがえるであろう。

マドゥラ島は、西から東へバンカランBangkalan、サンパン
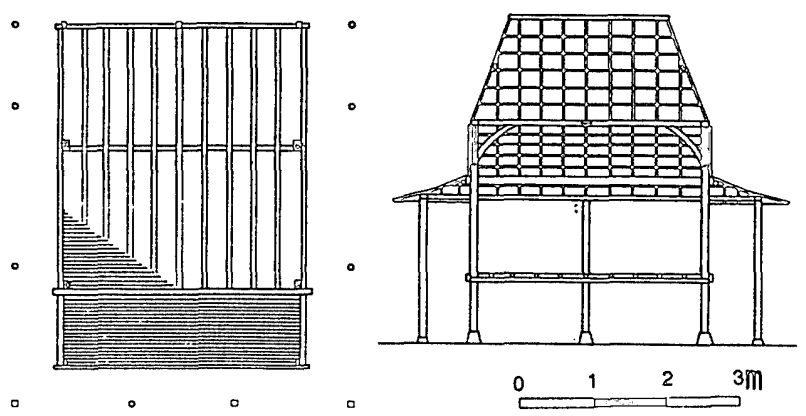

图 2 ランガール平・摡面图

Sampang、パムカサンPamekasan、スムヌップSumenupの 4つのカブ パテン kabupaten(県) に区分されているが、島全体を踏査した結果、 屋敖地レベルで平行二列対面型の住居配置を持つことは、島全体に共 通した特徽であることが分かった。平行二列対面型の住居配置をとら ない唯一の例外として、查部のデサ・ピンギール・パパスPinggir Papas があるか、これについては後述したい。多くの場合、屋敷地は、生垣 や柵によって区画されており、境界に沿って竹、果樹などの屋敷林が 作られている。分榑式の住居に挟まれた中庭は、タネアンtanean と呼 ばれ（規模の大きなものは夕ネアン・ランジャンtanean lanjang）、東 西に長くのびている。分榑式の住居の最も基本的な構成は、屋敷地北 側に中庭に南面してロマ・トング roma tonggu (主屋)、南側に中庭に 北面してダポールdapor (釜屋)、カンタン kantang (家畜小屋)など の付属屋が建つ。これらは全て土間式である。中庭の西端に建つラン ガール langgar（礼择棟: 図2）は、マドゥラ人の住居に独特なもので あり、付属屋のうち例外的に高床式である。

2-2 マドゥラ画部の主屡泟式

屋敷地の構成においては、原則的にマドゥラ島全体に共通の特徵が 見られるが、主屋の形式と付属屋の種類には地域差がある。 マドゥラ西部の主屋は、まず屋根形式によって、トロンペサン trompesan（切妻）と blimbingan"9(奇棟の四周に下屋を付加したもの) の二種類が区別される(図3)。前者がより古いとされるが、その構造 は小屋組を除くと同じである。パンパン・ラジャ pangpang raja と呼ば れる4本の柱の頭部が、ランパラン lamparan（桁）とブブンガン bubungan (梁) でつながれ、さらにその下に貫が入れられる。この部 分が小屋組を支える。下屋は構造的には独立したペアンペッpe'ampek （垂木受け）とパンパン・クニ pangpang kuni（垂木受けを支える柱） によって支えられる。

さらにマドゥラ西部の屋根形式に特徵的なのは、複数棈の主屋が下 屋部分で桁行き方向に連結されることである。最も一般的なのは二 槙が連続する場合で、ポトンガン potongan 亡呼ばれる（図 4)。また 三棟以上が連続する場合もあるが、これは切妻の屋根形式を持つ主屋 の多く残っているサンパン県に見られる。

主屋の平面構成は平入りで、きわめて単純である。中庭に面した主 屋前部のアンペル amper（テラス）とクナンガ・テドゥンkonanga tedhung (文字どおりの意味は寝室) からなる。ポトンガンの場合、ア ンペルも連続する。二棟の間の空間は室内化されており、ガン gang と呼ばれ通常は倉庫または小寝室として使われる。

マドゥラ島に特徵的な家具として、レンチャック lencakが挙げられ 

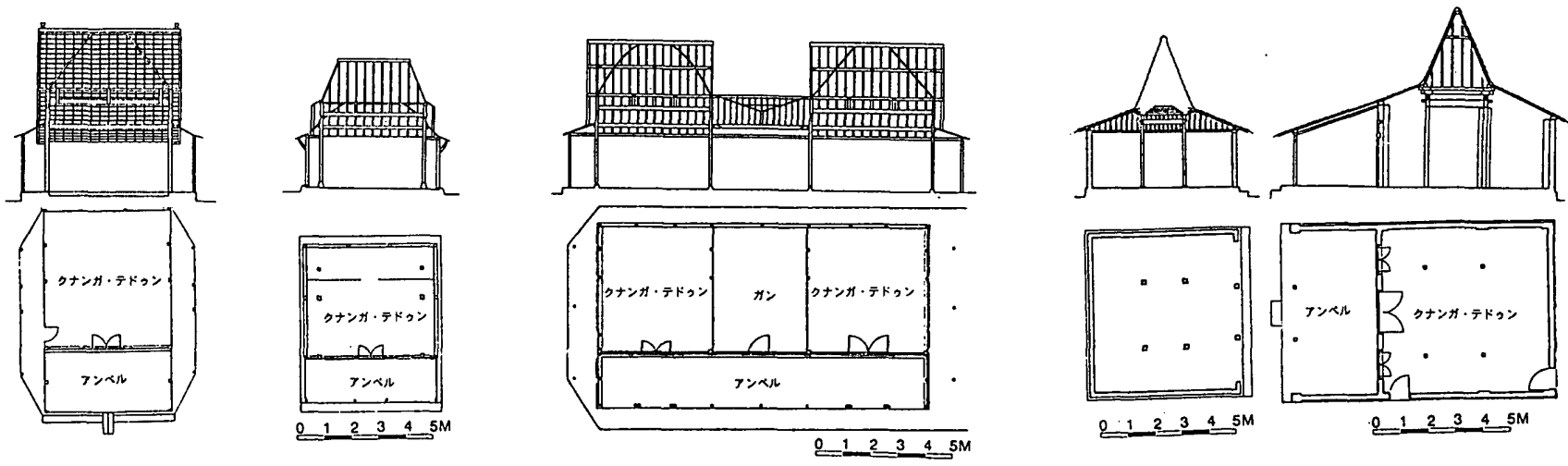

図 3

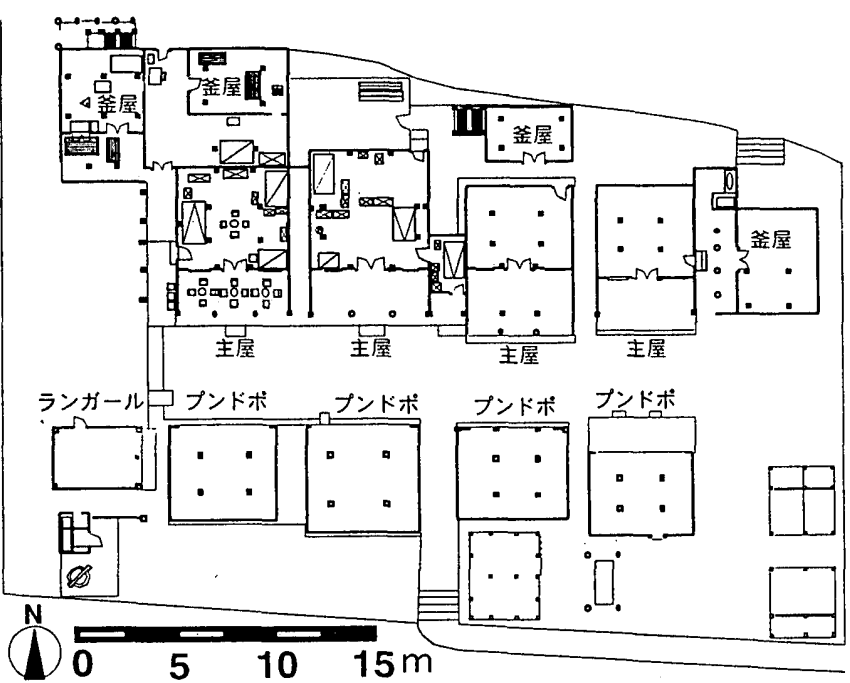

図 7 プンドポと主屋がクラスター型に眍置される屋敷地 (スムヌップ県グル・グル郡デサ・グル・グル)

る。これは一畳ほどの大きさの露台であり、主にアンペルに置かれ る。土間式住居での日常生活において高床の生活面を確保する重要 な家具である。また主屋内にはレンチャック・パレlencak palek(ベッ ド）とロマリ lomari（棚）が置かれる。

2-3 マドゥラ東部の主屋形式、プンドポ

マドゥラ東部の主屋はジャワと共通の屋根架構を持つ。"10 ジャワ のジョグロjoglo(急勾配の寄棟の四周に下屋を回した屋根型の住居) にあたる住居が、マドゥラ東部ではバンサール bangsal"11 (図 5)、リ マサン limasan (笴棟型) にあたる住居が、ペグン pegun 亡呼ばれる。 前者は後者より格式が高いものと考えられている。パチェナン pacenan (切妻型) は、マドゥラ東部では通常付属屋にしか用いられ ない。主屋が複数棟建つ場合、それぞれは独立し、主屋平面がマドゥ ラ西部のように連続することはない。

架構、部材名については、ほぼジャワの場合と同じである。中心 となる4本の柱はササカ sasaka と呼ばれる。ササカの頭部はランバ ン lambang (梁・桁) で連結され、その下にソンドゥッs sonduk (貫) が入れられる。この架構の中心部分全体で、コルビkorbi亡呼ばれる。 バンサールの場合、ランバンの上に、トンパン・サリ tompang sari
と呼ばれる特徴的な部材が、外側に持ち送られながら井桁状に重ねら れ、この上に小屋組と下屋の垂木が乗る。この段数が多いほど主屋の 格式が高いとされる。ペグンの場合はこの部材を持たない。

主屋平面は西部と同様に平入りで、アンペルと間仕切りのない室内 空間からなる。アンペルには机や椅子が置かれ、椅子座の浸透が見ら れる。平面構成の点では、マドゥラ東部とジャワは大きく巽なる。マ ドゥラ東部の場合には、ジャワでソントン・トゥンガに当たる聖なる 空間が欠如しているのである。"12マドゥラ東部では、主屋平面内で、 奥の壁を背にした向きで右(kanan)左(kacer)が認識されている。また主 屋の奥側がロオロ lo'olo(川の上流を示す集合名詞)と呼ばれる。・13

東部の集落に特徵的な付属屋として、従来ジャワの住居に固有の付 属屋と考えられてきたプンドポpendopoがある（図6)。バンサールや ジョグロと同じ架構を持つことと接客棟であることは、ジャワとマ ドゥラで共通しているのだが、マドゥラの場合に特徵的なのは、複数 のプンドポと主屋が、中庭を介して対面するように平行二列対面型に 配置されることである(図7)。ジャワでも一部に平行二列対面型の配 置が報告されているが、一般には単独て、プンドポ、主屋の順に、と もに正面を南向きに一直線に配置されると考えられている。“14

他の付属屋の持ち万は、基本的にマドゥラ島全体の特徴に一致す る。しかし、マドゥラ西部では原則的な配置が、ほぼ必ず守られる一 方で、しばしばマドゥラ東部ではランガールを欠いたり、主屋後部に 釜屋が付設される例が見られる。

\section{2-4 デサ・ピンギール・パバス}

デサ・ピンギール・パパスはスムヌップ県カリアングットKalianget 郡（クチャマタン kecamatan）の最南端に位置する漁村である。もと もとマドゥラ人の土着の集落であったが、後にバリの王国の軍隊やイ スラーム教を伝導したジャワの導師らが、住み着いたと言われる。”15

図8はカンポン（集落の下位単位）・アグンのRT8（RT:Rukun Tetangga、隣組）の西端部の配置図である。この集落の特徽は、南北 に細長い宅地割りである。この宅地割りに従い屋敷地内には、前から 順にプンドポ、主屋、釜屋が互いに中庭をはさんで、直線状に配置さ れる。これはマドゥラ島全体に共通した東西に長い平行二列対面型の 住居配置とは大きく異なり、むしろジャワに一般的な配置である。主 屋はマドゥラ東部に見られるバンサールであるが、その呼称は異な

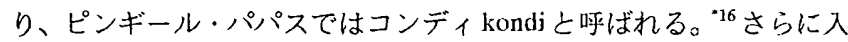
口の向きによって名称が区別され、入口が屋敷地の北側の場合は「プ 
ンドポ」、南側の場合は「ムンハダップ menghadap」と呼ばれる。ム ンハダップの文字どおりの意味は「面する、向かい合う」である。主 にRTの南半分の屋敷地が海に面するためと考えられるが、その別の 意味に「会う」があることを考えると、南から入る向きは、外来者 がその家の者に「会う」向きであると解釈もできる。

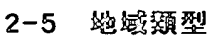

マドゥラ島の住居および集落は、屋敷地を構成単位とし、平入り の住居が平行二列対面型に並ぶ点で共通するが、主屋形式に着目す ると、パムカサンPamekasan 県を境界に、バンカランBangkalan 県 · サンパン Sampang 県を中心とした西部と、スムヌップSumenup 県を 中心とした東部に大きく地域分類できる（図9）。西部はマドゥラ島 に特有の主屋形式を持つのに対して、東部はプンドポの存在を含め、 ジャワと共通の住居形式を持つ。ピンギール・パパスの住居配置は マドゥラ島では特殊な事例であり、むしろジャワの住居配置と比較 してみる必要があると思われる。・17

\section{3.デサ・サンングラ・アグンの空間㮐成}

1858年にオランダ植民地政府が、直轄領としてパムカサン侯国を 編入し、さらに1864年にバンカラン侯国からサンパン県を分離する 以前は、マドゥラ島は西部のバンカラン、東部のスムヌップの両侯 国が強い支配力を持った。先に指摘した地域類型は、ほぼ、この侯 国の支配版図之一致する。そして当時、マドゥラとは、この西部の バンカラン侯国を指した。以下において、マドゥラ島に固有の主屋 形式が見られる西部の集落から、特に複数の主屋を持つタネアン・ ランジャンが多く見られるデサ（村）・サングラ・アグンを選び、そ の屋敷地の平面類型、生活行為之居住空間の関係について考察する。

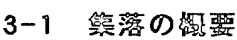

デサ・サングラ・アグンは、マドゥラ西部のバンカラン県ソチャ Socah 郡にある。デサ全体は、下位行政単位である 7 つのドゥスン dusun (住区) ${ }^{-18}$ からなる。そのうちデサの中心部にあるドゥスン・ サングラ・アグン・トゥンガ（図 10）の一画には、マカム・レンポ ンMakam Lempong と呼ばれる集落全体の共同墓地（図10：A）があ る。墓地の中心部には、一組の屋根を持つ特別な墓がある。これは

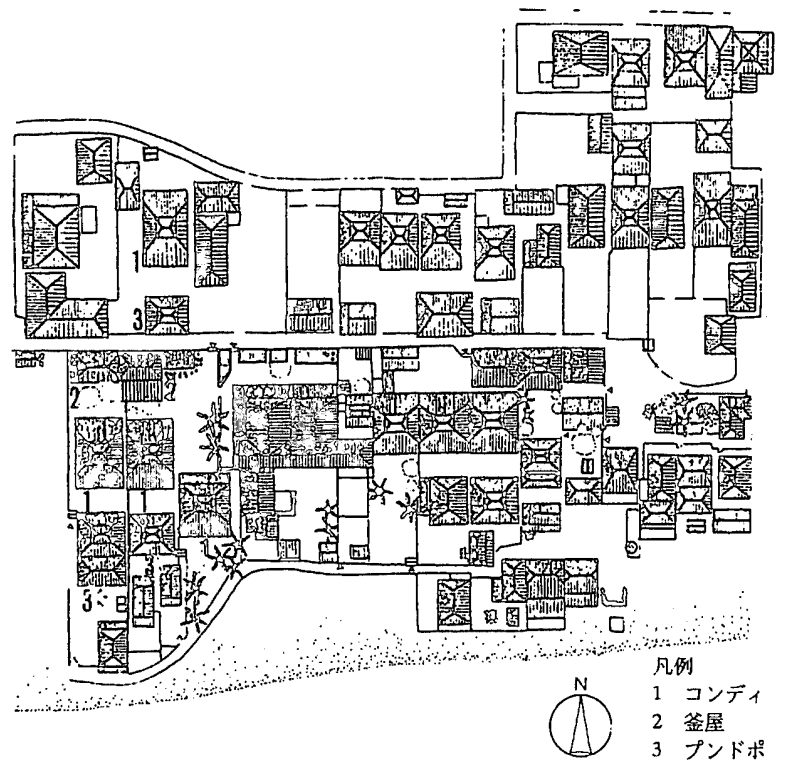

图8ピンギール・パパスRT8 西端部宣冠图
デサを開いた先祖である女性の墓であるという。この先祖の屋敷地 （図 10：B）は、同ドゥスンに現在もあり、直系の子孫であるハジ . マニサーHaji Manisah と呼ばれる女性が住み続けている。つまり、デ サは、同ドゥスンを中心に発展してきたのである。

以下で分析の対象としたのは同ドゥスン内から選定した屋敷地 28 事例（図10に番号を記入した屋敷地）である。

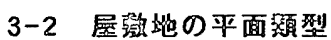

図 11 は、主に主屋および釜屋の位置に着目し、屋敷地を規模によ り分類したものである。付属屋のうち釜屋に着目するのは、その位置 亡数が屋敷地の規模の拡大と関係があると考えられるからである。

最も小規模な屋敷地は、中庭西側にランガール、北側に主屋、南側 に釜屋および家畜小屋からなる（stage1）。

次に考えられるのが、付属屋のうち釜屋が、主屋西僋 (ランガール の北側）に移動した段階である(stage2)。この段階で本来釜屋のある 位置が空地である $2 \mathrm{a}$ 型、また、家畜小屋を持たない場合、南側が全 く空地である $2 \mathrm{~b}$ 型の例がある。敷地に余裕のある比較的小規模な屋
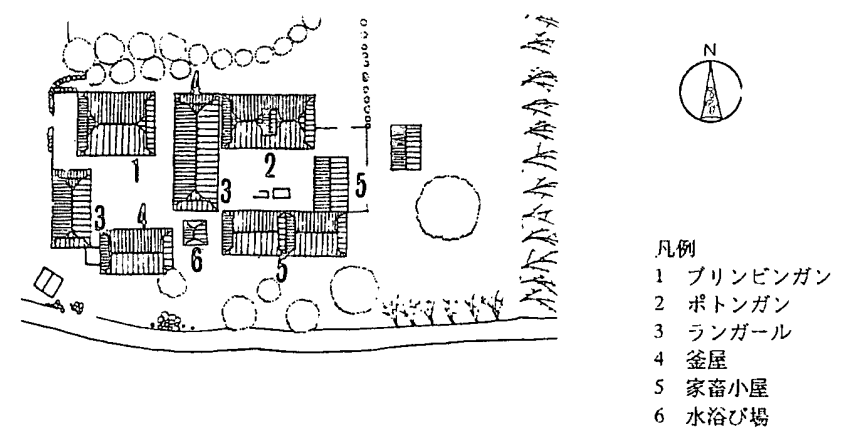

西部型の例:デ・アラン・アラン(バンカラン県トラガ㴫)
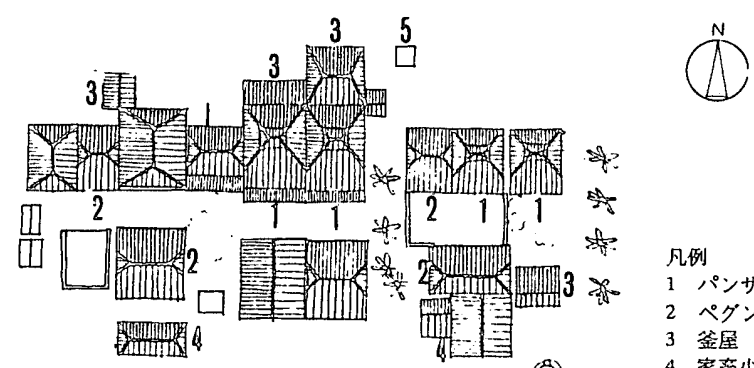

凡例 パンサール ペグン 3 鉒屋 4 家蓄小屋 5 水浴び場

彭部型の倒:デサ・ガプラ・バラット(スムヌップ県ガプラ郡)

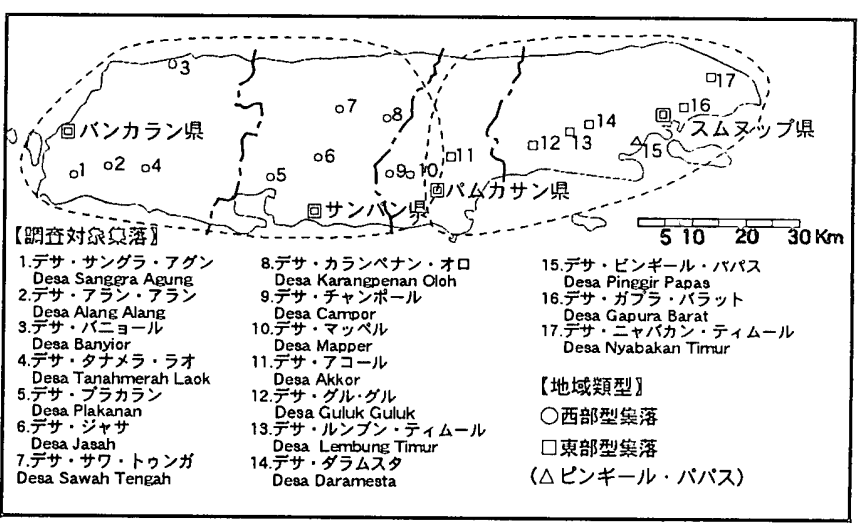

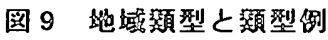


敷地でも、主屋西侧への釜屋設置例が見られるが、その理由のひと つには、屋敷地北西に位置する井戸と釜屋の距離的な近さがもたら す水回りの便の良さが挙げられる。

マドゥラ島では、一般に屋敷地内に住む世帯数が増え、主屋を増 築する必要がある場合、新しい主屋は古い主屋の東倒に建てられる。 その結果、中庭北側半分に主屋が並び、南側半分に付属屋が並ふ。し かし、デサ・サングラ・アグンの場合、こうした屋敷地は少ない。中 庭北側に主屋が一棟の小規模な屋敷地でも、すでに南側にも主屋が 見られる (stage3)。3a 型は、南側に家畜小屋を残しており、2a 型か ら最も自然に南側に主屋が建てられたものと考えることができる。 $3 \mathrm{~b}$ 型は、すでに牛小屋なよ゙の比較的規模の大きな家畜小屋を持たな い場合であり、2b 型の空地が建て詰まった場合と考えられる。3c型 は、屋敷地の南側に主屋を建てる際に、家畜小屋が主屋の裏庭側に 移されたと考えられる事例である。最も基本的な構成を残した $3 \mathrm{a}$ 型 と同様に多く見られるパターンが $3 \mathrm{~d}$ 型である。この場合、家畜小屋 はランガールの南側に設置されている。

主屋がさらに建設され、屋敷地の規模が拡大すると、しばしば東 端に 2 番目の釜屋が建設される(stage4)。

以上のように、屋敷地の構成は、主屋や付属屋の配置に着目する と、屋敷地の拡大過程と対応しながら、4 段階に分類できる。

\section{3-3 家族構成と住居の所有関係}

屋敷地内には拡大家族が住むが、複数の主屋のそれぞれには核家
族単位で居住する。一般に、マドゥラ島では妻方居住婚が行われ、結 婚後も屋教地内に留まり主屋を相続するのは女性だとされる ${ }^{19}$ 。調査 事例では全主屋の 3 割弱に当たる51例中14例が男性によって相続さ

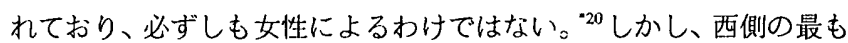
重要な主屋であるポトンガンを相続、またはそこで親と同居するの は、実に 16 例中 14 例が女性（娘夫婦）であった。ポトンガンに限れ ば、その相続は女性によると考えられる。

原則として主屋の配置順序は、世代順および同世代内では長幼順に 西から東へ並ぶ。判断可能な屋敷地 17 例" ${ }^{15}$ のうち、7例が、図 12 に 示すように、こうした基本パターン（A）を守っていた。

その他の屋敷地では、世代または同世代内の長幼関係と主屋配置が 部分的に逆転するパターン (B) が見られる。親子間での逆転 (B1) が3例、(兄弟) 姉妹間での逆転（B2）が2例（重複は1例:B3）であ る。姉妹間の逆転が起こる場合、注意したいのは、しばしば、年老い た親世帯が、ランガールに住む例があることである。多くの子供が結 婚し独立した主屋を必要亡するようになる亡、親が自らの主屋を明け 渡すのである。早く結婚する長子世帯などは、当初別棟に住み、親が 死去し主屋が空いた後、または第二子以降の世帯のために主屋を明け 渡した後も、当初の棟に住み続ける場合があることが、部分的な逆転 の起こる大きな原因と考えられる。

付属屋の所有関係が大きく変化するのは、屋敷地の規模が拡大し、 釜屋が二棟になるパターン（C）である。これは図 11 の stage4の場

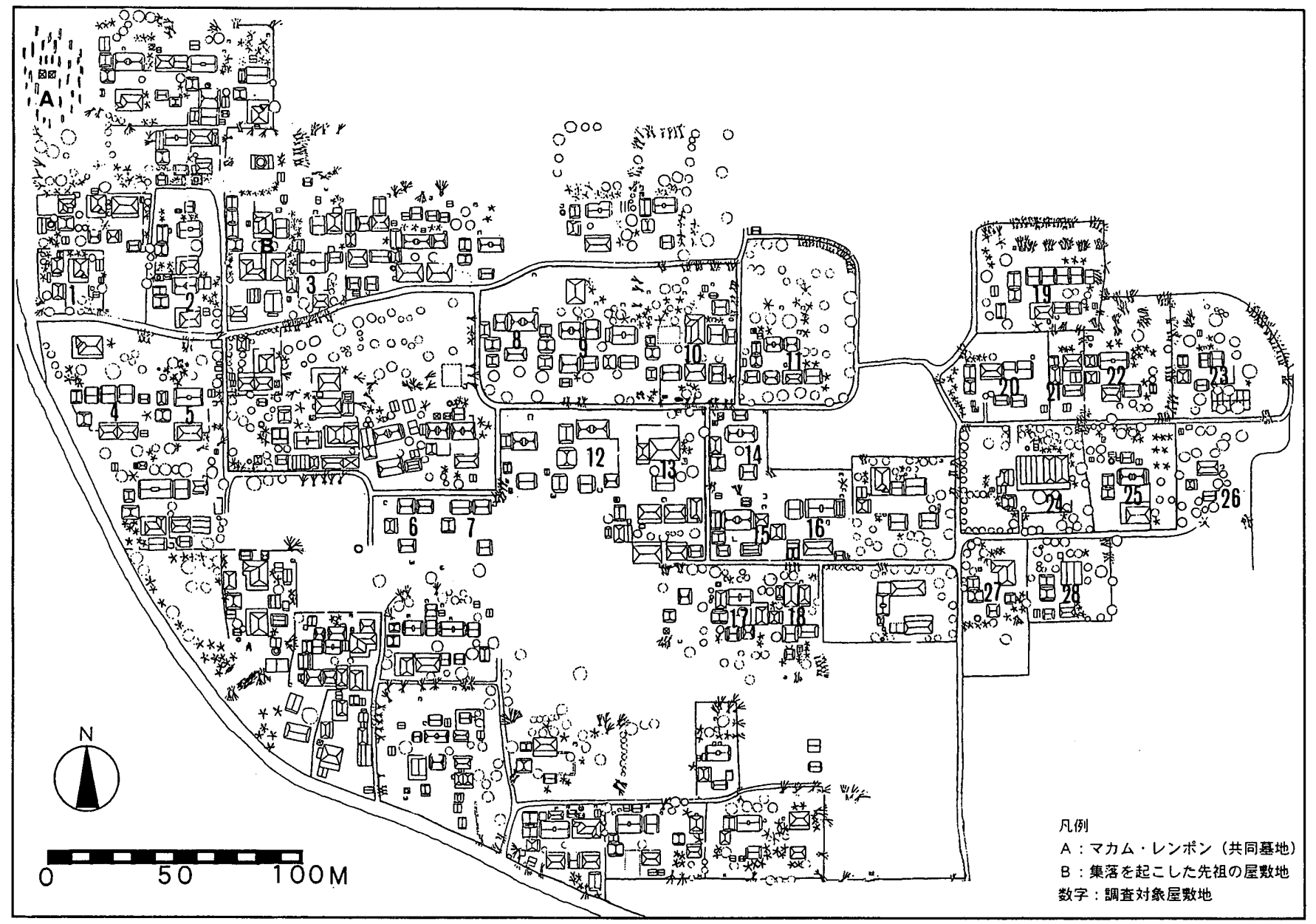

図 10 ドゥスン・サングラ・アグン・トゥンガ眍置図 
合だが、居住者の家族構成亡釜屋の所有関係を見る亡、二通りの場 合がある。居住者全員が血縁関係で結ばれる場合 (C1) と血縁関係 の意識されない二つの拡大家族が住む場合 (C2) が、それぞれ 2 例 見られる。後者の場合、中庭をはさんで向かい合う棟と㫫か、ひと つの家族により所有され、屋敷地が東西に分割され所有されている。

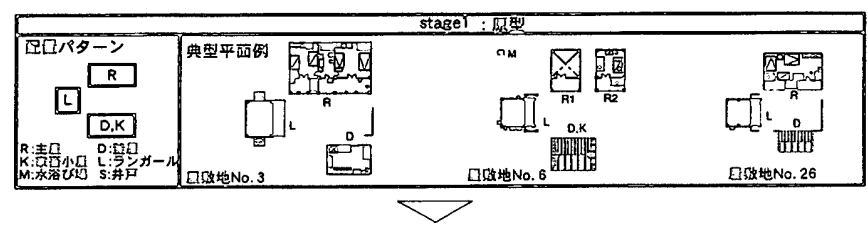

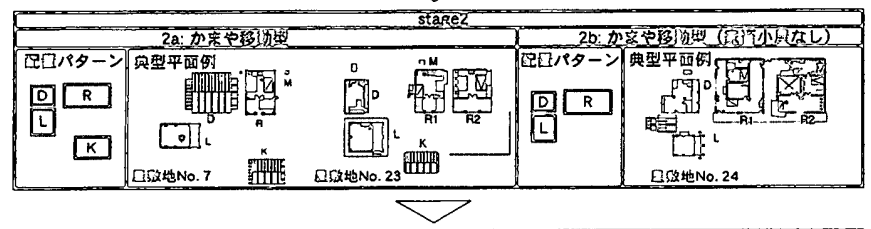
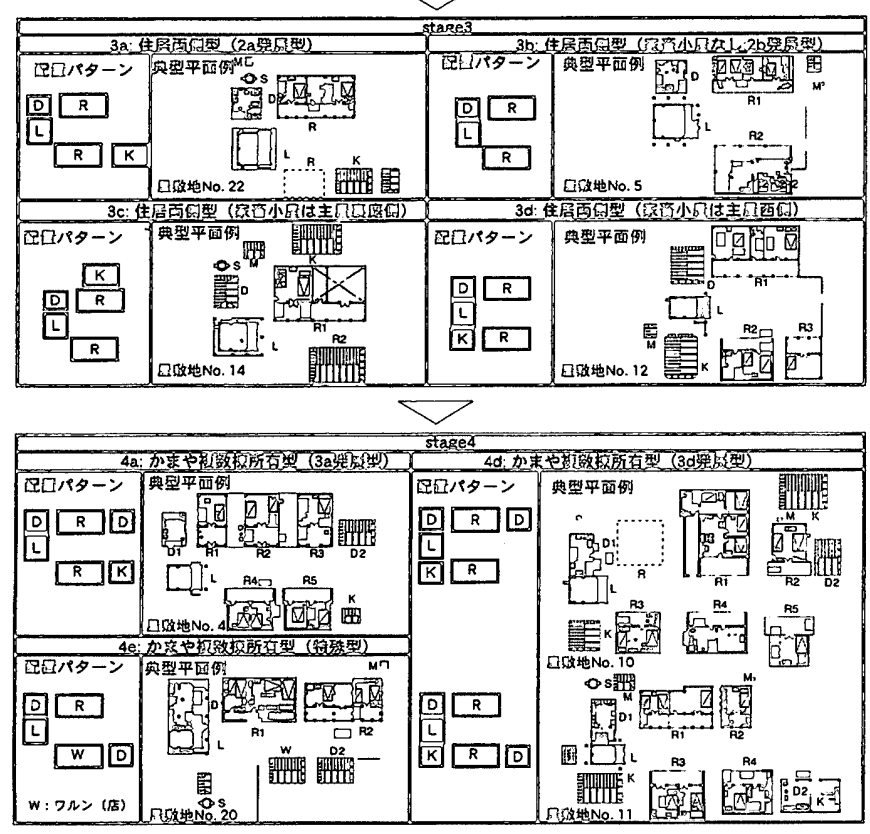

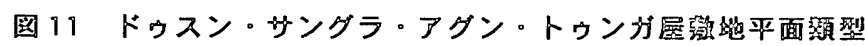

\section{3-4 生活行第と居位空間の関係}

就寝、食事、接客、イスラームの礼詳といった生活行為が、住居の どこで行われるかについて、世代と性別に注意し見てみたい（表 1)。 1)锶毁々核家族ごとに、それぞれの主屋内で就寝するのが一般的であ るが、特徵的なのは、ランガールが利用される場合があることであ る。ランガールで就寝する者には、年齢や性別により、大きく二つの 層がある。上述した子供世帯に主屋を譲った親（6例）上未婚男子 (8 例）である。未婚男子の場合、10歳ごろから家族と離れてランガール で寝るようになる。つまり、ランガールは主屋に赛場所のない者を吸 収する役割も果たす。また男性の訪問客もランガールに泊まる。 2)念菲 食事の場所については、ばらつきがあるが、いくつか特徵的 な点を举げると以下のようである。

・男女が別々の場所で食事をとる例が見られる(7 例)。男性がラン ガールで女性がアンペルで食事する例、男性がランガールで女性が釜 屋内で食事する例などがある。

・祖父母などの老人が、他の家族と離れて食事をとる傾向がある(5 例）。家族内で、祖母のみが釜屋で食事をする例、祖父のみがランガー ルで食事をとる例などがある。

全体の特徴として、主屋内で食事をとる例は、レンガ造の主屋の居 間が多く、伝統的な不造主屋内で食事をとる例はほとんどない。

3)邆客 伝統的な木造主屋には居間がないのに対し、新しいレンガ造 の主屋には、居間を持つものがある。

木造主屋の場合、接客の行われる場所は、ほぼ共通している。男性 客の場合はランガール、女性客はアンペルのレンチャックである。

居間を持つレンガ造の主屋でも、その約半数では木造主屋と同じ接 客の仕方である。一方で居間が利用される場合も、女性客に限って居 間でもてなされ、男性客は必ずランガールでもてなされる。

つまり、居間を持つレンガ造の主屋に建て替わっても、基本的には 木造主屋での接客の仕方が受け継がれていると考えられる。

山イスラーム讙の礼绿 マドゥラ人はインドネシアでも敬虔なイス ラーム教徒として知られる。全体の9割以上の屋敷地でランガールで 礼拝を行う。男女の性別にかかわらないことに、特に注意したい。

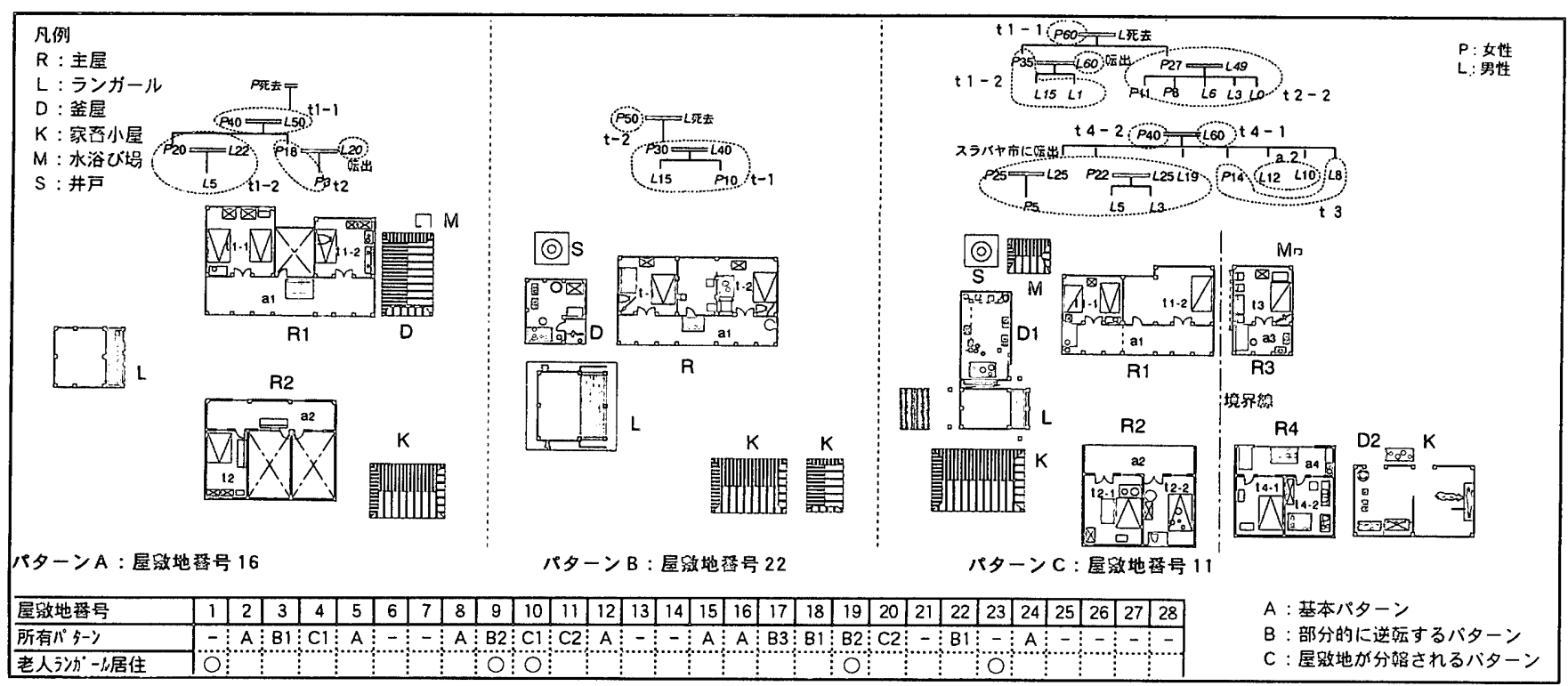

国 12 家維成と住居の所有闑係 


\section{3-5 デサ・グル・グルにおける生活行為と居住空間の関係}

地域類型を基にした比較を行うため、マドゥラ東部の集落・スム ヌップ県グル・グル郡デサ・グル・グルを取り上げてみたい（表 2$) 。$ デサ・サングラ・アグンでは、生活行為が行われるのは、ランガー ルを中心とした付属屋や主屋前部のアンペルなよ゙中庭回りの空間に おいてであった。一方で東部では、上述したようにランガールを欠 くなよ゙、付属屋の持ち方が巽なる場合がある。その場合、生活様式 が異なることが予想されるのであるが、調査事例から見ると以下の ようである。特にランガールの有無に注意して、生活行為と居住空 間の関係を見たい。調查事例として、ランガールを持つもの7例（屋 敷地番号 $1,3,5,6,7,12,13$ )、持たないもの 8 例（屋敷地番号 $2,4,8,9,10,11,14,15$ )、合計 15 の屋敷地を選んだ。

1)就囬 核家族単位で、それぞれの主屋で就寝するのは、西部之同 じである。しかし大きく異なるのは、ランガールで就寝する者が、ほ とんよ゙ないことである。西部とは巽なり、老人も必ず主屋内で葠起 きする。未婚男子のランガールでの寝起きも見られない。未婚男子 の隔離就寝には、主屋に単独で寝起き (3例)、釜屋で寝起き (1 例)、

\section{表 1 デサ・サングラ・アグンにおける生活行為と居住空間の関係}

\begin{tabular}{|c|c|c|}
\hline 就㩧者 & 就限场所 & 屋数地舀甹 \\
\hline 末婚男子 & ランガール & $2,5,8,9,10,15,20,21,25,27,28$ \\
\hline 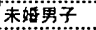 & 梠诸主屋 & 11,20 \\
\hline 末楿男子 & 谓主堂 & 12,13 \\
\hline 菜㜣男子 & 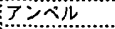 & 1120 \\
\hline 表人............. & $3 y+\pi$ & $19,10,15,19,21,23,27$ \\
\hline 焉 & 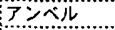 & 6 \\
\hline 茹性 & 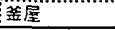 & 19,27 \\
\hline
\end{tabular}

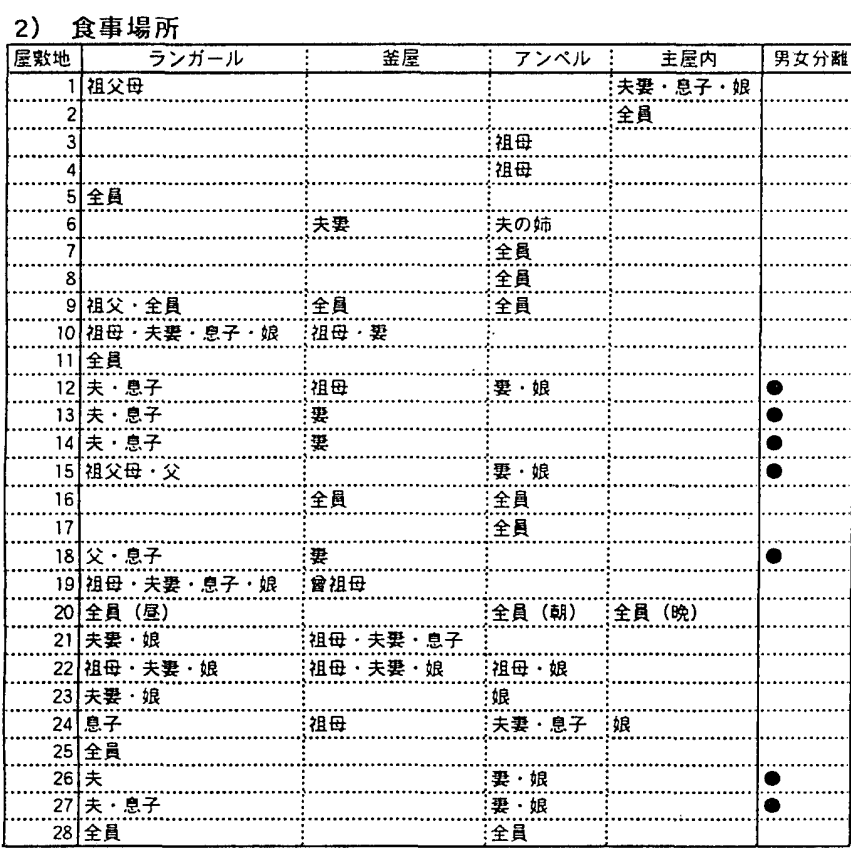

\section{3）接客場所}

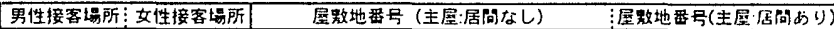

\begin{tabular}{|c|c|c|c|}
\hline & & & \\
\hline ランガール & アンペル & $3,4,7,8,9,10,11,12,14,15, \$ 6,17,20,21,22,26$ & $\$ 1,5,19,24$ \\
\hline 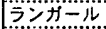 & 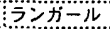 & 6,23 & $18,25,27$ \\
\hline 居为 & 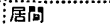 & & 13 \\
\hline
\end{tabular}

4) 礼撞場可

\begin{tabular}{|c|c|c|}
\hline 男性殺洋場所 & 女珄礼择坦所 & 屋数地番号 \\
\hline ランガール & ランカール & $1,2,3,5,6,7,8,9,10,11,12,13,14,15,16,17,18,19,20,21,22,23,24,26,27,28$ \\
\hline 居间 & 闾 & 25 \\
\hline 㮛宝 & 掫室 & 4 \\
\hline
\end{tabular}

レンガ造の主屋の寝室で従兄弟同士で寝起き（1例）の例がある。

2)食事 釜屋内で食事をする例が、ほとんどである。主屋後部に尃用 の釜屋が設けられる例が、しばしば見られるのだが、釜屋の共用、専 用に関わらず、食事は釜屋でとられる。その結果、酉部のようにうン ガールなどの半戸外空間を利用したり、男女が違う場所で食事をする 傾向はない。専用の釜屋があるため、性別というょり、むしろ核家族 ごとに分かれて食事をしている。

3)接客 ランガールのある屋敷地では、大きく二つの場合がある。男 性がランガール・女性がアンペルの場合（3 例）上男性がアンペル・ 女性が主屋内の場合（3 例）である。

ランガールのない屋躈地では、男性がアンペル・女性が木造主屋内 またはレンガ造主屋の居間でもてなされる場合が多い(5例)。一方で 男女とも同じ場所の場合もある（アンペル2 例、主屋内 1 例）。

全体に男女の接客場所が区別される点では、西部亡共通するが、必 ずしもランガールが利用されていない場合のある点で異なる。接客 は、性別による区別をしつつも、主屋で行われる場合が多い。

4)イスラームの礼拝 ランガールのある屋敷地のうち、5例ではラ ンガールで礼择するが、うち4例は男性のみであり、女性は主屋内で 専用の台を用いて礼洋する。西部のように、男女ともランガールを利 用するのは 1 例のみである。また 2 例ではランガールを利用しない。

ラシガールのない屋敷地では、男女とも主屋内で礼拝を行う。

\section{3-6 考察}

デサ・サングラ・アグンの住居空間の利用を見ると、就寝、接客に ついては、屋敷地の規模に関拐らず性別により主屋とランガールを明 確に分けて利用するという、共通の傾向がある。食事の場所は他の生 活行為と比較すると多様だが、ランガールやアンペルなどの半戸外空 間でよられることが多く、性別による分離もある程度見られる。しか し、大きく巽なるのが礼拝であり、男女にかかわらず、ほぼ必ずラン ガールで行われる。16 世紀にイスラーム教がジャワより伝来され最 初のイスラーム侯国が起こった西部は、イスラームが最も強く浸透し た地域である。マドゥラ島の住居で唯一高床式の建物であるランガー ルは、礼拝の場となりイスラームと強く結合し、メッカの方向である 屋敷地西側に残されたのではないかと考えられる。さらに重要な点と

表 2 テサ・グル・グルにおける生活行為と居住空間の関係

\begin{tabular}{|c|c|c|c|}
\hline 就提者 & 践骎䍜所 & 屋数地息号 $\left(j / h^{\circ}-l\right.$ 有り) & 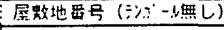 \\
\hline 未㜣男子 & 木造主屋 & 3.7 & 4 \\
\hline 未婚男子 & 金屋 & & 9 \\
\hline 沫㮩男子 & 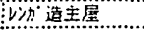 & & 15 \\
\hline 老人 & 主屋 & $2.8 .14,15$ & 5.6 \\
\hline
\end{tabular}

\begin{tabular}{|c|c|}
\hline 食電場所 & 屋数地番号 \\
\hline 共用蕀屋 & $1,2,4,5,6,7,8,10,11,12,15$ \\
\hline 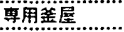 & $2,3,9,13$ \\
\hline 茷屋前了シベ & 14 \\
\hline
\end{tabular}

\begin{tabular}{|c|c|c|c|}
\hline & & 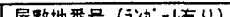 & \\
\hline ランカーール & アンベル & $1,7,12$ & \\
\hline アシベ & アンベル & 5 & 9,15 \\
\hline アンベル & 梏主至内 & $3,6,13$ & $2,8,10$ \\
\hline 米茫 & 阁间 & & 4011 \\
\hline 筈间 & 居間 & & 114 \\
\hline
\end{tabular}

\section{4) 新择場所}

\begin{tabular}{|c|c|c|c|}
\hline 男性礼拝姞所 & 女佳礼洋場所 & 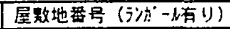 & 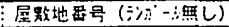 \\
\hline ランガール & ランガール & 3 & \\
\hline ラシカール & 术造主屋内 & $0.7,12,13$ & \\
\hline 木造主屋内 & 木造主屋内 & 5,6 & $2,8,9,10,11,14,15$ \\
\hline 㷊造主豦内 & アシベル & & 4 \\
\hline
\end{tabular}


して、ランガールが保持されたことで、中庭まわりの空間を利用し た生活の保存につながったことが指摘できる。

一方でデサ・グル・グルでは、生活の中心は、より主屋に移行し ている。ランガールの利用の仕方にばらつきがあることに顕著に現 れているように、生活様式が変化しつつあると考えられる。また、 そうした変化は、ランガールを欠く例、主屋後部に専用の釜屋が設 けられる例のように住居の構成の変化にも現れている。

\section{Q.まと的}

1)マドゥラ島の屋敷地の構成は、インドネシア各地に見られる平行 二列対面型の住居配置の原型をよく残している。本稿では具体的に その基本構成を明らかにした。

2)マドゥラ島の住居は主屋形式により、西部亡東部の二つに地域類 型される。西部はマドゥラ特有の主屋形式を持ち、東部はジャワと 共通の架構を持つ主屋形式である。しかし東部は、ジャワでソン トゥン・トゥンガにあたる聖なる空間を持たない点が大きく異なる。 3)マドゥラ西部の典型として、デサ・サングラ・アグンの空間構成 を平面類型によって明らかにした。また建物の所有関係、生活行為 と居住空間の関係について明らかにした。

4)マドゥラ西部は屋敷地の規模に関わらず、生活様式は一定である。 イスラームの導入が生活、住居様式の保持に影響したと考えられる。 5)東部は、生活の中心が主屋へ移行しており、付属屋を利用する平 行二列対面型の住居配置の空間利用の特性が失われつつある。

注䣋

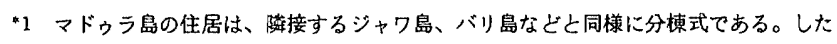

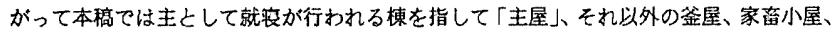
礼洋楝などを「付属屋」と呼ふ。また「主屋」と「付属屋」を合わせて「住居」之呼ふ心。

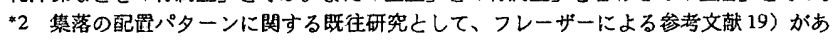
る。フレーザーは平行二列対面型の配置について、ドンソン文化に尖するものとするが、 その名称についての統一的な表現はしていない。また考古学からは、偊辺による参考文献

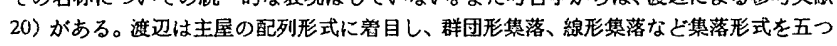
に分額しているが、インドネシア等の地域的な势組みは教量されていない。しかい、主屋 の列效を分頑朝亡する涟辺の分類は、インドネシアの場合についてす、平行二列対面型の 下位分類を行う上ては示袋的である。集落や屋㩆地における圾も大きな男女の空間分けを 念頭におくと、主屋の列效により以下の特徴が举げられる。トラジャ、トバ、ロンボク・ スンバルン等の一列型ては、主屋が女性の空間、对面する狡合の下部に張られた露台が男 性の空間として機能する例が見られる。一方、二列型では、スンバの渴合のように主屋内 て男女の空間分隻を解决する例、アチェのメナウサ一(新りの家)、二アスの男性集会場 などの独立の建物によって男性の空間を㴶保する例が見られる。

最近の研究甥向では、インドネシア大学のG.チャジョノが心になり編集を進めてい るIndonesian Heritageがあるが、 Linear, Compound, Longの3形式が述へられるに留まって いる(国立民族学博物館・佐藤浩司氏の御教授による。

*3 参考文献1)による。

“4 マドゥラ島の文献目䱚として、I. Farjon, MADURA AND SURROUNDING ISLANDS, The Hague, 1980 があるが、建筑学からの既往研究は、ほとんと揭载されておらず、現地

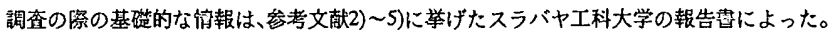
特に文故 2)はマドゥラ息全体をある程度粗羅しており、储報の中心となった。

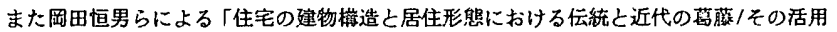
の可能生(2)」があるが、断片的てマドゥラ島全体についての視野に久けている。

"5 地域領型の抽出のために住居配置の実测を行った捰落名とその位置は図9に示した。

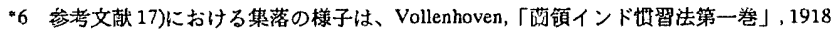
および Kuntowijoyo, Social Change in an Agrarian Society:Madura 1850-1940,1980による。

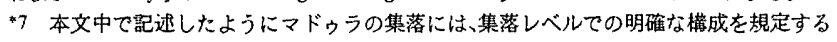
ような規則や建物はない。田町の中に単独て存在する屋聂地与多い。また後のケースス タディの事例からも分かるように、生活のほとんどは屋歌地内て完結している。

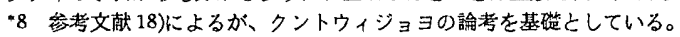

"9 blimbingは英語のstar fruitsにあたる果物の名称である。奇槽や下屋の腢が面取りされ た形か故射状に見えるためこのように呼ばれるのてあろう。

"10 シャワの住居については既往研究は多いか、現地研究者によるものは、参考文献6) 〜9)が主なものてある。文献6)は多くのスケッチと写真を交え、ショョグロの細かい分額と 措造について競明がれているが、建物自体の物理的な跑述に留まっている。一方て文献 7)は、ジョグロの持つ象篗的な意味をヒンドゥーの世界観から明らかにしている。文献8)

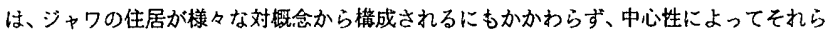

が統一されることを述へる。文献9)は、ジョグロ以外にす、ジャワの住居形式について広く 触扎ている。

"11 バンサール、プンドポについては、スムヌップ県デサ・グル・グルにおいて、部枋寸法 や建物全体の比例が、时（アス夕）、尋(ドゥパ）指（ジュリ）足（プチャ）などの人体寸法 によって決定されていることが確認された。列えぱ、4本柱（ササカ）間のスパンの場合、 析行方向 : 梁行方向 = 15 プチャ: 10 プチャ など。また、バンサールの名称はジョグジャカ ルタのクラトン内の建物の名称にも使用されていることを付品しておく。

"12 マドゥラ東部ではパムカサン県のかつての県知索の住居等においてもンントゥン・トゥ ンガは見られなかった。調亘篹囲では貴族住居においても聖なる空間が全く欠如していた。 *13 国立民族学博物館・佐藤浩司氏によって、北海岸のスムヌップ県アンブンテン郡サロペ ン村には、相対方位を残し、絶対方位から見て左右が逆衙する例が礁認されている。またジャ ワとマドゥラてもともと海を意味したlor, laokが絶対方位ては、ジャワとマドゥラで逆向き であり、それぞれ北、南として残っている。こうした絶対方位への棃行還程・程度の違いに より、ジョグジャカル夕には、相対方位の左右から見て、本来東に来るへき女性の染間が西 にある住居の例が文献16)に報告されている。また文献8)でも釜屋が西に位置するとされる。 クラトンとタマン・サリの関係も同様である。

"1417世紀にマタラム王国の王宮の設けられた中部ジャワ・ジョグジャカルタ近郊のコタ. グデ地区について、ガジャマダ大学グループによる参考文献10,11)など一連の報告专の中て、 コタ・グテ地区の住居配置が五つに類型され、椱数槙並んだプンドポとダルム(主屋)が対 面配置される例が示されている。また文献11)には、同様の住居配置か、ジャワ北部沿岸の クドっスのカウマン地区にも見られるとの記述がある。

*15 参考文献 3)による。

*16 通常、マドゥラ東部ては、コンディは、バンサールの槙飾りを指す名称である。

"17 ピンギール・パパスでは、RT8 の住居配置を見る限り、坌屋の位置は主屋後部でる。 これに対して、ジョグジャでは釜屋は西㑡にある。本来左と結びつく女性の空間が、ジョグ シャては西（右）に位置することは、今後の検討を要するが、ジャワの王権の確立時期およ びその北海岸から南海岸への位圆の移動に関係する可能性がある。

*18 サングラ・アグン・バラットBarat、サングラ・アグン・トゥンガTengah、ソロ Sorok、 ムラグン・スラタンMuragung Selatan、ムラグン・ウタラUtara、ムラグン・ティムールTimur、 アンソカAnesokah の7 住区である。

*19 参考文献 12)による

*20 HRAF(Human Relations Area files)には、マドゥラ人の親疾原理は、双系制とある。 *21判断ができない屋敂地は、主屋が一槙のみの揚合、一世帯のみしか居住していない揭合 などがある。

*22 その他の揭所で就榷する少数例には以下がある。

・姓が釜屋て就较する(2 例)。屋數地No.1 ては柤父母がランガールで靬起きしているた め、さらに上の世代の曾柤母は釜屋で鼠起きする。No.9は主屋を改筑中であり、母と娘が釜 屋で起きする。

・アンペルのレンチャックで就安する(3 例)。No.14は、例外的にランガールがない。その ためアンペルのレンチャックを利用する。

・末婚男子が主屋内にひとり、または裉数で震起きしている(4例)。No.2,14は、空き家と なった出稼ぎ中の世帯の主屋て㖡起きする例でる。No.16,17はレンガ造の主屋内に間比切

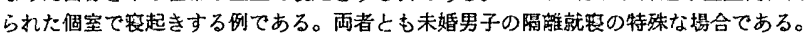

\section{参考文献}

1) R. Tan, Description of the Domestic Architecture of South Bali, Yale University, 1966

2) Institut Teknologi Surabaya(ITS), Arsitektur Traditional Madura, 1976

3) ITS, Bangunan Traditional Jawa Timur, 1974

4) ITS, Rumah Traditional Desa Pinggir Papas, 1983

5) ITS, Arsitektur Madura di Bangkalan, 1983

6) Hamzuri, RUMAH TRADITIONAL JAWA, Departemen Pendidikan dan Kebudayaan,1980

7) J. Prijotomo, IDEAS and FORMS JAVANESE ARCHITECTURE, Gadjah Mada University Press, 1984

8) G. Tjahjono, Center and Duality in the Javanese Dwelling, "Dwellings Settlements \& Tradition", University Press of America, 1989

9) R. Ismunandar K, joglo, Dahara Prize,1993

10) Wondo-Sigit, KOTAGEDE-Between the Two Gates, Gadjah Mada Univ., 1986

11) Suryanto and Indanoe, KOTAGEDE - A traditional Settlement, Gadjah Mada Univ., 1987

12) Huub de Jonge, MADURA DALAM UMPAT ZAMAN,KITLV,1989

13) Roy Jordan, Fork Medicine in Madura,1988

14) Abudurachman, Sejarah Madura Seyayang Pandang, 1971

15) Zein M. Wiryoprawiro, ArsiteKtur Tradisional Madura Sumenup, ITS, 1986

16) Gadjah Mada Univ., Kuliah Kerja Jogjakarta, 1975

17) 田中則婎,「19世紀マドゥラの村落社会」:南方文化」，天理南方文化研究会, 1985

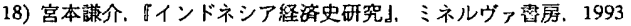

19)D.フレーザー、『未開社会の集落」，渡辺洋子訳，井上贵院，1984

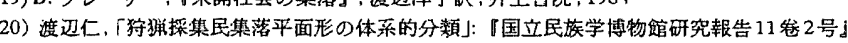
国立民族学博物馆，1986 